\title{
Optimasi Keakuratan Dimensi dan Kekasaran Permukaan Potong Material Akrilik dengan Proses Laser Menggunakan Metode Taguchi dan PCR- TOPSIS
}

(Optimization of the Accuracy of the Dimensions and Roughness of Cutting Surface Acrylic Materials by Laser Process Using the Taguchi and PCR-TOPSIS Method)

Adi Nugroho ${ }^{a}$, Adhi Setya Hutama ${ }^{b}$, Cahyo Budiyantoro ${ }^{c}$

${ }^{a, b}$ Program Studi Teknologi Rekayasa Perancangan Manufaktur, Politeknik ATMI Surakarta Jl. Adisucipto/ Jl. Mojo No.1 Surakarta

e-mail: adi.nugroho@atmi.ac.id ${ }^{\mathrm{a}}$, adhisetyahutama@gmail.comb

${ }^{\mathrm{C}}$ Program Studi Teknik Mesin, Fakultas Teknik, Universitas Muhammadiyah Yogyakarta Jalan Brawijaya Tamantirto, Kasihan, Bantul, DI Yogyakarta, Indonesia, 55183 e-mail: cahyo_budi@umy.ac.id ${ }^{\circ}$

\section{Abstrak}

Mesin laser banyak digunakan di berbagai jenis industri, baik di industri manufaktur dan di industri kerajinan / kreatif. Mesin laser sering digunakan untuk memotong dan mengukir objek yang memiliki bahan yang sulit dan sifat kontur yang tidak dapat dilakukan oleh mesin konvensional. Bahan akrilik sering ditemukan di industri kerajinan dan kreatif yang menggunakan mesin laser. Bahan akrilik dapat diolah menjadi produk bernilai tinggi. Ada berbagai macam produk yang terbuat dari akrilik yang dibentuk melalui proses pemotongan laser, seperti gantungan kunci, souvenir, piala, aksesoris, barang dagangan, plakat, dan produk kreatif. Proses pembuatan menggunakan mesin laser ternyata juga ada masalah, seperti kerataan produk, dan panjangnya tingkat persimpangan. Berdasarkan literasi, peneliti mengoptimalkan beberapa parameter yang ditemukan pada mesin pemotong laser, seperti kecepatan potong, energi yang dibutuhkan, dan jarak nozzle. Hasilnya adalah kehalusan produk yang dihasilkan, dan dimensi sesuai dengan desain. Metode pengujian optimasi yang digunakan adalah metode Taguchi yang dikombinasikan dengan metode PCR (Process Capability Ratio), dan TOPSIS

Kata kunci: Mesin Laser Cutting, Acrylic, PCR-TOPSIS, Taguchi

\section{Abstract}

Laser machines are widely used in various types of industries, both in the manufacturing industries and in the craft/creative industries. Laser machines are often used to cut and engrave objects that have difficult material and contour properties that conventional machines cannot do. Acrylic materials are often found in the craft and creative industries that use laser machines. Acrylic materials can be processed into high-value products. There are various kinds of products made from Acrylic which are formed through a laser cutting process, such as key chains, souvenirs, trophies, accessories, merchandise, placards, and creative products. The process of making using a laser machine turns out that there are also problems, such as flatness of the product, and the length of the intersection rate. Based on the literacy, the researcher optimizes several parameters found on laser cutting machines, such as cutting speed, required energy, and nozzle distance. The result is the fineness of the product produced, and the dimensions according to the design. The optimization testing method that used was the Taguchi method which was combined with the PCR (Process Capability Ratio) method, and TOPSIS (Technique for Order Performance by Similarity to Ideal Solution).

Keywords: Cutting Laser Machine, Acrylic, PCR-TOPSIS, Taguchi 


\section{Pendahuluan}

Mesin laser banyak digunakan dalam berbagai jenis industri, baik dalam industri manufaktur maupun industri kerajinan/industri kreatif. Pemanfaatan mesin laser pada industri manufaktur lebih ditujukan untuk pemotongan plat besi dan pembuatan kontur. Sedangkan pada industri kerajinan/industri kreatif, mesin laser diaplikasikan untuk pembuatan produk kerajinan, seperti membuat lukisan dari granit bahkan yang berbahan dasar kulit hewan, pembuatan gantungan kunci, asesoris, menggrafir produk [6]. Dari pemaparan tersebut, mesin laser sering digunakan untuk memotong dan menggrafir benda yang mempunyai sifat material dan kontur yang sulit yang tidak bisa dikerjakan oleh mesin konvensional. Pada gambar 1.1, dijelaskan tentang produk yang dihasilkan dari penggunaan mesin laser.

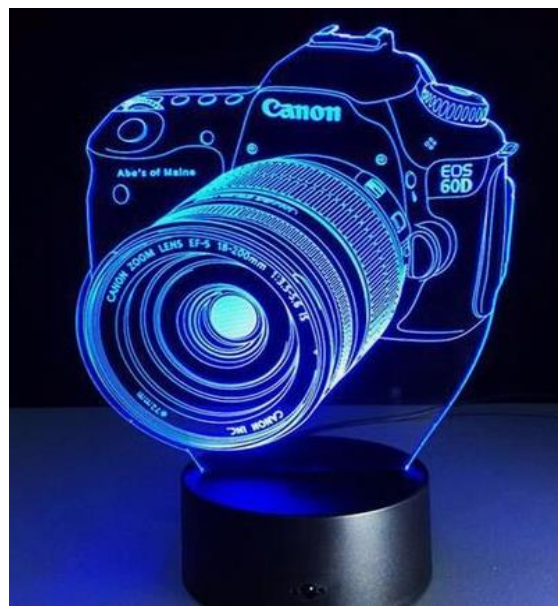

Gambar 1.1. Contoh Produk dari Mesin Laser (sumber: id.pinterest.com- 7 Color 3d Camera Led Lamp)

Keunggulan penggunaan mesin laser adalah proses produksi dapat berjalan dengan cepat, karena mesin laser dapat menerima data langsung dari komputer [1], mampu memotong benda-benda rumit, mampu membuat grafir seperti yang dikehendaki dan mampu meminimalkan material sisa [7]. Selain itu, keunggulan mesin laser adalah dapat digunakan pada berbagai jenis material seperti plat, kaca, kayu, kertas karton, dan akrilik.

Industri kreatif dan kerajinan sekarang ini banyak menggunakan mesin laser cutting untuk proses produksi dengan bahan material akrilik. Pada artikel yang dibuat Bisnis.com, dan dikutip dalam penelitian [8] menyebutkan bahwa material akrilik dapat diolah menjadi produk bernilai jual tinggi. Akrilik diperkenalkan sebagai material pengganti kaca, karena struktur materialnya yang tidak mudah pecah dan mempunyai ketebalan yang seragam. Terdapat berbagai macam produk yang berbahan akrilik yang dibentuk melalui proses laser cutting, seperti gantungan kunci, suvenir, piala, asesoris, merchandise, plakat, serta produkproduk kreatif seperti yang ditunjukan pada Gambar 1.2.

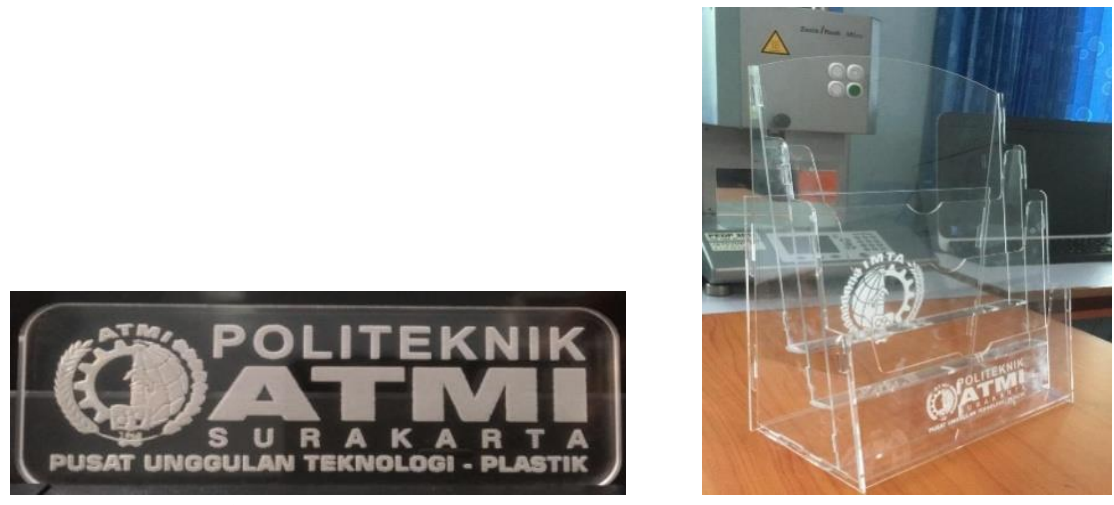

Gambar 1.2. Produk-produk berbahan dasar akrilik 
Proses pembuatan dengan menggunakan mesin laser ternyata juga terdapat permasalahan yang pada umumnya berupa kerataan permukaan dan ketepatan ukuran dari produk yang dipotong. [7] juga menyebutkan beberapa kerugian dari proses mesin laser, antara lain, mesin laser mengkonsumsi daya yang tinggi dan penggunaan daya berdasarkan proses yang digunakan. Dengan demikian, efek penggunaan sinar laser yang membuat suhu menjadi panas. [9] mengemukakan terdapat beberapa solusi untuk mengatasi permasalahan pada proses laser cutting dengan bahan dasar akrilik, salah satunya adalah mengoptimasi variabel-variabel yang membuat produk tersebut bagus, dengan kerataan permukaan yang mampu disesuaikan. Variabel tersebut antara lain: jarak nozzle terhadap permukaan akrilik yang akan dikerjakan, jenis laser yang dipilih, tekanan gas untuk memotong dan mengukir, kecepatan potong, daya/energi pemotongan; [9].

Berdasarkan literasi tersebut, hal yang dilakukan dalam penelitian adalah pengoptimalan beberapa parameter yang terdapat pada mesin laser cutting, seperti kecepatan potong, energi yang digunakan, dan jarak nozzle. Hasil yang diharapkan adalah untuk mencari parameter yang optimal sehingga didapatkan kualitas yang optimal dari kekasaran permukaan dan keakuratan dimensi dari produk yang dipotong sesuai dengan desain yang dibuat. Metode pengujian optimasi yang akan digunakan adalah metode Taguchi yang dipadukan dengan metode PCR (Process Capability Ratio), dan TOPSIS (Technique for Order Performance by Similarity to Ideal Solution).

\section{Metode}

\subsection{Alat dan Bahan}

Penelitian ini menggunakan Mesin Laser Cutting Hans Yueming tipe CMR0604-BR yang berada di Laboratorium Pusat Unggulan Teknologi Plastik-Politeknik Atmi Surakarta. Spesimen dibuat dengan menggunakan material akrilik dengan dimensi $20 \times 40 \mathrm{~mm}$ dan ketebalan $3 \mathrm{~mm}$ (Gambar 2.1).

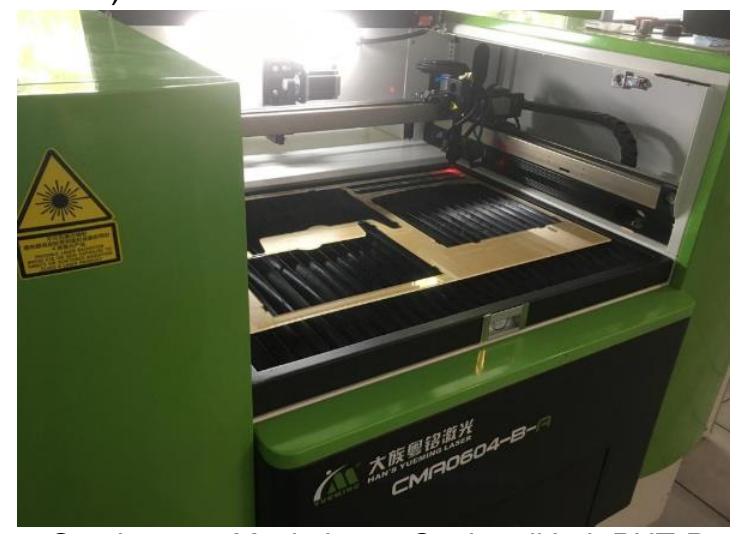

Gambar 2.1. Mesin Laser Cutting di Lab PUT-P

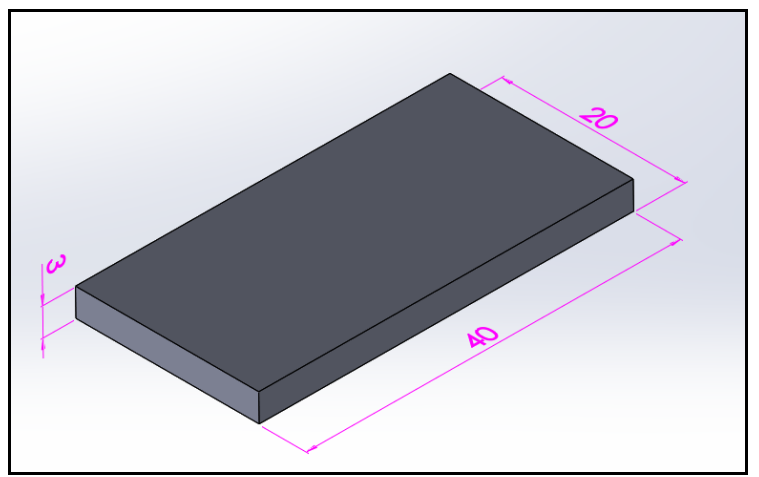

Gambar 2.2. Desain Spesimen yang Diujikan (akrilik 20x40×3 mm) 
Pengukuran kekasaran permukaan sampel dilakukan untuk mengetahui tingkat nilai $\mathrm{Ra}$ (penyimpangan rata-rata dari garis rata-rata profil) permukaan yang terkena pemotongan laser. Pengukuran Ra menggunakan alat surface roughness tester-Mitutoyo, model: SJ201P, sedangkan pengukuran dimensi sampel menggunakan jangka sorong dengan ketelitian 0,02 mm Brand Mitutoyo 505 series seperti gambar 2.3.

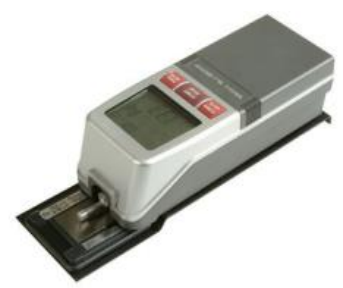

(a)

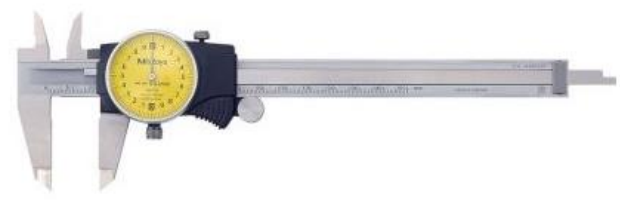

(b)

Gambar 2.3. (a) Roughness surface test. (b) Dial caliper

\subsection{Metode}

Proses penelitian diawali dengan studi literatur tentang penggunaan mesin laser cutting. Terdapat beberapa variabel pemrosesan yang perlu dianalisis pada mesin laser cutting supaya didapatkan bentuk yang tepat sesuai dengan desain, dan kerataan pemotongan yang halus. Variabel tersebut adalah kecepatan pemotongan, persentase energi dan jarak nozzle. Kecepatan potong perlu dipotimalkan karena jika kecepatan dimaksimalkan, maka mengakibatkan benda akrilik tidak terpotong, sedangkan jika kecepatan tersebut diperlambat, maka dapat merusak benda. Pada penelitan ini,kisaran kecepatan potong mesin laser cutting adalah $6-12 \mathrm{~mm} / \mathrm{s}$.

Pengoptimalan energi yang diperlukan untuk mengetahui besaran energi yang dikeluarkan pada saat proses pemotongan, sehingga didapatkan efektivitas penggunaan energi. Mesin Laser Cutting Hans Yueming tipe CMR0604-BR memiliki kisaran persentase energi untuk perpotongan adalah $80-95 \%$. Pengoptimalan jarak nozzle terhadap material benda diperlukan karena berpengaruh terhadap titik fokus laser ketika melakukan proses pemotongan. Parameter jarak nozzle terhadap benda kerja adalah $24-26 \mathrm{~mm}$. Setelah didapatkan parameter yang diujikan, langkah berikutnya adalah penentuan parameter yang menjadi hasil dari yang diuji cobakan, antara lain luas area pemotongan sesuai dengan desain, dan kekasaran permukaan pada permukaan sisi potong.

Metode yang digunakan dalam optimasi parameter dilakukan dengan cara studi literatur tentang metode optimasi yang memiliki parameter terukur, dan parameter hasil lebih dari satu parameter, sehingga diperoleh pengujian yang menggunakan metode taguchi yang digabungkan dengan metode PCR-TOPSIS.

Metode Taguchi merupakan metode yang berbasis eksperimen dalam mengoptimasi proses kerja, parameter, maupun material yang ditunjukan untuk mendapatkan kombinasi yang sesuai agar tercapai efektivitas produksi. Metode Taguchi memiliki keuntungan dalam hal uji coba, karena parameter terukur telah dimodifikasi menjadi susunan orthogonal array. Selain itu, metode Taguchi juga menstransformasi data yang diperoleh dalam bentuk Signal to Noise Ratio (SNR). SNR mengakomodasi berbagai jenis optimasi yang diperlukan oleh peneliti, dan diberikan 3 pilihan, yaitu smaller the better, nominal the better, dan larger the better.

PCR merupakan metode yang digunakan untuk melihat suatu proses atau produk baik tersebut apakah berada dalam batas toleransi yang telah ditentukan [2]. TOPSIS adalah salah satu metode pengambilan keputusan dengan sejumlah kriteria yang beragam atau disebut juga MADM (Multi-Attribute Decision Making), yang harus dipertimbangkan dan masing-masing kriteria itu memiliki nilai bobot tertentu, dengan tujuan untuk mendapatkan 
solusi optimal atas suatu permasalahan [4]. Prinsip dasar dari TOPSIS adalah pemilihan alternatif harus memiliki jarak paling kecil untuk nilai ideal positif dan jarak paling besar untuk nilai ideal negatif [5]. Solusi ideal positif merupakan nilai terbaik yang dicapai untuk setiap atribut, sedangkan solusi ideal negatif merupakan nilai terburuk untuk setiap atribut.

Penelitian dikerjakan di Laboratorium Testing unit kerja Pusat Unggulan Teknologi Plastik-Politeknik Atmi Surakarta. Dimulai dengan identifikasi permasalahan yang terdapat pada mesin laser, studi literatur berkaitan tentang kegunaan mesin laser dan metode Taguchi PCR-TOPSIS yang digunakan untuk mengoptimalkan parameter dari mesin laser. Parameter respon yang dibentuk adalah dimensi yang sesuai dengan ukuran desain (20x40) $\mathrm{mm}$ dengan ketebalan akrilik $3 \mathrm{~mm}$, dan kekasaran permukaan.

\section{Hasil dan Pembahasan}

3.1 Penentuan Parameter Terukur dan Orthogonal Array

Pada penelitian ini terdapat 3 parameter yang dioptimalkan, yaitu: kecepatan potong, power, dan jarak nozzle laser terhadap permukaan sampel. Setiap parameter ditentukan 4 level yang nantinya akan digunakan untuk mengetahui pada level berapakah parameter tersebut optimum (Tabel 3.1).

Tabel 3.1. Parameter terukur dan Level

\begin{tabular}{ccccc}
\hline Parameter & \multicolumn{5}{c}{ Level } \\
\cline { 2 - 5 } & 1 & 2 & 3 & 4 \\
\hline Kecepatan Potong (mm/s) & 6 & 8 & 10 & 12 \\
\hline Persentase Energi (\%) & 80 & 85 & 90 & 95 \\
\hline Jarak Nozzle (mm) & 8 & 9 & 10 & 11 \\
\hline
\end{tabular}

Berdasarkan pemilihan parameter dan level tersebut, langkah berikutnya adalah penentuan orthogonal array, yang berfungsi untuk acuan dalam pembuatan dan pengujian sampel. Orthogonal array dari Metode Taguchi yang dipilih adalah L16. L16 adalah terdapat 16 pengujian pembuatan sampel dan nantinya akan di-uji tentang optimasi dari proses pembuatan produk dengan menggunakan mesin laser (Tabel 3.2).

Tabel 3.2. Orthogonal Array L16

\begin{tabular}{ccccccc}
\hline No & $\begin{array}{c}\text { Kecepatan } \\
\text { Potong }\end{array}$ & $\begin{array}{c}\text { Persentase } \\
\text { Energi }\end{array}$ & Jarak Nozzle & Persentase Luas Sampel & $\begin{array}{c}\text { Persentase } \\
\text { Kekasaran permukaan }\end{array}$ \\
\hline $\mathbf{1}$ & 6 & 80 & 8 & $\mathrm{X} 1$ & $\mathrm{Y} 1$ \\
\hline $\mathbf{2}$ & 6 & 85 & 9 & $\mathrm{X} 2$ & $\mathrm{Y} 2$ \\
\hline $\mathbf{3}$ & 6 & 90 & 10 & $\mathrm{X} 3$ & $\mathrm{Y3}$ \\
\hline $\mathbf{4}$ & 6 & 95 & 11 & $\mathrm{X} 4$ & $\mathrm{Y} 4$ \\
\hline $\mathbf{5}$ & 8 & 80 & 9 & $\mathrm{X} 5$ & $\mathrm{Y} 5$ \\
\hline $\mathbf{6}$ & 8 & 85 & 8 & $\mathrm{X} 6$ & $\mathrm{Y}$ \\
\hline $\mathbf{7}$ & 8 & 90 & 11 & $\mathrm{X} 7$ & $\mathrm{Y} 7$ \\
\hline $\mathbf{8}$ & 8 & 95 & 10 & $\mathrm{X} 8$ & $\mathrm{Y} 8$ \\
\hline $\mathbf{9}$ & 10 & 80 & 10 & $\mathrm{X} 9$ & $\mathrm{Y} 9$ \\
\hline $\mathbf{1 0}$ & 10 & 85 & 11 & $\mathrm{X} 10$ & $\mathrm{Y} 11$ \\
\hline $\mathbf{1 1}$ & 10 & 90 & 8 & $\mathrm{X} 11$ & $\mathrm{Y} 12$ \\
\hline $\mathbf{1 2}$ & 10 & 95 & 9 & $\mathrm{X} 13$ & $\mathrm{Y} 13$ \\
\hline $\mathbf{1 3}$ & 12 & 80 & 11 & $\mathrm{X} 14$ & $\mathrm{Y} 14$ \\
\hline $\mathbf{1 4}$ & 12 & 85 & 10 & $\mathrm{X} 15$ & $\mathrm{Y} 15$ \\
\hline $\mathbf{1 5}$ & 12 & 90 & 9 & $\mathrm{X} 16$ & $\mathrm{Y} 16$ \\
\hline $\mathbf{1 6}$ & 12 & 95 & 8 & & \\
\hline
\end{tabular}




\subsection{Perhitungan Signal to Noise Ratio (SNR)}

Nilai SNR diperoleh dari hasil pengolahan data orthogonal array dengan 16 percobaan, dan didapatkan data pada Tabel 3.3. Pemilihan karakteristik SNR dengan respon dimensi berbeda dengan karaketeristik SNR dengan respon kekasaran permukaan. SNR Larger the Better digunakan untuk respon dimensi karena nilai yang terbesar merupakan nilai yang mendekati keakuratan dimensi, dan SNR Smaller the Better digunakan untuk respon kekasaran permukaan, karena nilai terkecil dari SNR disimpulkan sampel memiliki tingkat kakasaran yang paling sedikit.

Rumus untuk SNR dengan karakteristik Larger the Better adalah sebagai berikut:

$$
\eta_{j}^{i}=-10 \log _{10}\left[\frac{1}{l} \sum_{k=1}^{l} \frac{1}{\left(y_{j k}^{i}\right)^{2}}\right], 0 \leq y_{j k}^{i}<\infty,
$$

Rumus untuk SNR dengan karakteristik Smaller the Better adalah sebagai berikut:

$$
\eta_{j}^{i}=-10 \log _{10}\left[\frac{1}{l} \sum_{k=1}^{l}\left(y_{j k}^{i}\right)^{2}\right], 0 \leq y_{j k}^{i}<\infty,
$$

Di mana :

$y_{j k}^{i}=$ nilai respon ke-j pada percobaan

Berdasarkan nilai SNR pada Tabel 3.3 Pada percobaan ke-15 terlihat kondisi optimum untuk parameter respon dimensi dengan keakurasian 97,86, sedangkan percobaan ke-9

\begin{tabular}{|c|c|c|}
\hline \multirow{2}{*}{ No } & \multicolumn{2}{|r|}{ SNR } \\
\hline & Luas Sampel & kekasaran permukaan \\
\hline 1 & 97.0707 & 21 \\
\hline 2 & 96.47875 & 30.6 \\
\hline 3 & 96.5264 & 14.6 \\
\hline 4 & 96.3312 & 14.6 \\
\hline 5 & 90.2118 & 13 \\
\hline 6 & 97.4657 & 25 \\
\hline 7 & 95.6264 & 13.8 \\
\hline 8 & 96.5286 & 18.2 \\
\hline 9 & 96.8231 & 11.8 \\
\hline 10 & 96.67625 & 18.6 \\
\hline 11 & 96.7242 & 23.4 \\
\hline 12 & 97.317 & 22.2 \\
\hline 13 & 96.7731 & 19.4 \\
\hline 14 & 97.5144 & 14.6 \\
\hline 15 & 97.8614 & 21 \\
\hline 16 & 96.97185 & 44.2 \\
\hline
\end{tabular}
adalah kondisi optimum dari kekasaran permukaan dengan nilai kecatatan 11,8.

\subsection{Penghitungan Nilai PCR-SNR}

Kemampuan proses digunakan untuk mengetahui apakah suatu proses berada antara spesifikasi atas dan bawah [3]. Suatu proses dapat dikatakan baik, apabila berada dalam \pm 3 standar deviasi rata-rata. Nilai PCR-SN Ratio diperoleh dari transformasi nilai SN Ratio dari setiap variabel respon. PCR-SNR dihitung menggunakan rumus sebagai berikut :

$$
C_{j}^{i}=\frac{\eta_{j}^{i}-\bar{x}_{\eta_{j}}}{3 s_{\eta_{j}}}
$$


Di mana :

$\bar{X}_{x y j}=$ Rata - rata sample untuk SNR pada respon ke-j

$S_{w_{j i}}=$ Standar deviasi untuk SNR pada respon ke-j

$C_{j}^{i}=$ Nilai PCR-SNR setiap level i pada respon ke-J

Tabel 3.4. Nilai PCR SNR

\begin{tabular}{rcc}
\multirow{2}{*}{ No } & \multicolumn{2}{c}{ PCR SNR } \\
\cline { 2 - 3 } $\mathbf{1}$ & Luas Sampel & Kekasaran permukaan \\
\hline $\mathbf{2}$ & 0.176133 & 0.072457 \\
\hline $\mathbf{3}$ & 0.175059 & 0.104075 \\
\hline $\mathbf{4}$ & 0.174792 & 0.051379 \\
\hline $\mathbf{5}$ & 0.163688 & 0.051379 \\
\hline $\mathbf{6}$ & 0.17685 & 0.046109 \\
\hline $\mathbf{7}$ & 0.173513 & 0.085631 \\
\hline $\mathbf{8}$ & 0.17515 & 0.048744 \\
\hline $\mathbf{9}$ & 0.175684 & 0.063235 \\
\hline $\mathbf{1 0}$ & 0.175418 & 0.042157 \\
\hline $\mathbf{1 1}$ & 0.175505 & 0.064553 \\
\hline $\mathbf{1 2}$ & 0.17658 & 0.080361 \\
\hline $\mathbf{1 3}$ & 0.175593 & 0.076409 \\
\hline $\mathbf{1 4}$ & 0.176938 & 0.067187 \\
\hline $\mathbf{1 5}$ & 0.177568 & 0.051379 \\
\hline $\mathbf{1 6}$ & 0.175954 & 0.072457 \\
\hline & & 0.148866 \\
\hline
\end{tabular}

\subsection{PCR-TOPSIS}

Metode Topsis digunakan untuk penentuan jarak terdekat dengan solusi ideal positif dan jarak terjauh dengan solusi ideal negatif (Kusumawardani, 2015). Nilai Topsis digunakan untuk menentukan kondisi optimal dari respon multikriteria.

Tabel 3.5. Hasil Perhitungan Topsis

\begin{tabular}{rccc} 
No & di + & di- & PCR-TopSis \\
\hline $\mathbf{1}$ & 0.077416 & 0.030334 & 0.281522754 \\
\hline $\mathbf{2}$ & 0.046212 & 0.061969 & 0.572822896 \\
\hline $\mathbf{3}$ & 0.098159 & 0.009535 & 0.088535153 \\
\hline $\mathbf{4}$ & 0.098118 & 0.009631 & 0.089381349 \\
\hline $\mathbf{5}$ & 0.102757 & 0.014432 & 0.123149786 \\
\hline $\mathbf{6}$ & 0.06459 & 0.04348 & 0.402330708 \\
\hline $\mathbf{7}$ & 0.100603 & 0.007735 & 0.071399189 \\
\hline $\mathbf{8}$ & 0.086395 & 0.021217 & 0.197160207 \\
\hline $\mathbf{9}$ & 0.107382 & 0.001884 & 0.017242221 \\
\hline $\mathbf{1 0}$ & 0.085126 & 0.022499 & 0.209049286 \\
\hline $\mathbf{1 1}$ & 0.069516 & 0.03826 & 0.354995655 \\
\hline $\mathbf{1 2}$ & 0.073595 & 0.034267 & 0.317690628 \\
\hline $\mathbf{1 3}$ & 0.082542 & 0.025108 & 0.233240225 \\
\hline $\mathbf{1 4}$ & 0.098384 & 0.009243 & 0.085882241 \\
\hline $\mathbf{1 5}$ & 0.07766 & 0.0303 & 0.28066172 \\
\hline $\mathbf{1 6}$ & 0.012266 & 0.106722 & 0.896913508 \\
\hline & & &
\end{tabular}

\subsubsection{Penentuan Nilai Parameter Optimum}

Tabel 3.6. Kondisi Optimum dari nilai TOPSIS

\begin{tabular}{cccc} 
Level & $\begin{array}{c}\text { Kecepatan } \\
\text { Potong }\end{array}$ & $\begin{array}{c}\text { Persentase } \\
\text { Energi }\end{array}$ & $\begin{array}{c}\text { Jarak } \\
\text { Nozzle }\end{array}$ \\
\hline $\mathbf{1}$ & 0.258066 & 0.163789 & 0.483941 \\
\hline $\mathbf{2}$ & 0.19851 & 0.317521 & 0.323581 \\
\hline $\mathbf{3}$ & 0.224744 & 0.198898 & 0.097205 \\
\hline $\mathbf{4}$ & 0.374174 & 0.375286 & 0.150768 \\
\hline
\end{tabular}


Nilai PCR-TOPSIS digunakan sebagai acuan untuk menentukan parameter optimal. Rata-rata dari tiap parameter dan level dihitung sehingga diketahui mean rata-rata terbesarnya. Pada tabel 3.6 dijelaskan tentang kondisi optimum dari nilai level di setiap parameter. Pada parameter kecepatan potong dan persentase energi mempunyai nilai ratarata terbesar pada kondisi level 4, sedangkan jarak nozzle nilai terbesar terletak pada level 1. Dengan demikian, dapat disimpulkan untuk parameter kecepatan potong $12 \mathrm{~mm} / \mathrm{s}$, persentase energi yang dikeluarkan mesin laser cutting sejumlah $95 \%$ dan jarak nozzle $8 \mathrm{~mm}$ merupakan parameter optimum untuk pembentukan produk akrilik dengan dimensi 20x40 $\mathrm{mm}$, dan kekasaran permukaan mendekati $\mathrm{Ra}=0,02 \mu \mathrm{m}$.

\section{Kesimpulan}

Berdasarkan hasil pengamatan dan pembahasan tersebut, maka optimasi parameter dengan metode Taguchi yang mempunyai multikriteria respon, dan dipadukan dengan metode PCR Topsis dapat menentukan parameter optimum mesin laser cutting untuk pemotongan produk akrilik yang mempunyai dimensi $20 \times 40 \times 3 \mathrm{~mm}$ dan kekasaran permukaan $R a=0,02 \mu \mathrm{m}$. Parameter kecepatan potong yang optimum adalah $12 \mathrm{~mm} / \mathrm{s}$, persentase energi yang dikeluarkan adalah $95 \%$ dan jarak nozzle adalah $8 \mathrm{~mm}$.

Untuk penelitian selanjutnya, diharapkan terdapat penelitian untuk menguji optimasi parameter yang digunakan mesin laser cutting untuk mendapatkan grafir yang sesuai dengan kebutuhan customer, sehingga penggunaan mesin laser cutting dapat dimaksimalkan sepenuhnya.

\section{Daftar Pustaka}

[1] Samarya, T, Y. Aplikasi Laser Co2 Untuk Pemotongan (Cutting) Material Menggunakan Mesin Cnc (Control Numeric Computer). UNPAD:Jurnal FMipa. 2015:10 (1)

[2] Liao H,C. Taguchi's Multi- Using PCR-TOPSIS to Optimize response. Journal Manufactur Technology. 2003: 22: 649-655.

[3] Rinanto, A, Nugroho,A, Prasetyo, H, Pujiyanto, E,. Kekuatan tarik dan Konsumsi Energi Proses Fused Deposition Modelling Spesimen ASTM D638 Menggunakan Metode Taguchi dan PCR-TOPSIS. Yogyakarta: ICST UGM. 2018

[4] Winarni,S, Suningsih, N, Amzania T,G. Penerapan Optimasi Multirespon dengan Metode Grey Taguchi Topsis. Seminar Staistika. Bandung: Universitas Padjajaran. 2017

[5] Rao, R. Decision Making in the Manufacturing Environment Using Graph Theory and Fuzzy Multiple Attribute Decision. New York: Springer. London Heidelberg. 2013.

[6] Gunawan S. Kontribusi Hasil Pelatihan Cnc Advanced Terhadap Perkembangan Industri Kreatif Indonesia. Thesis. Bandung: Universitas Pendidikan Indonesia. 2014

[7] Arifin, S. Pengaruh Variasi Cutting Speed Terhadap Kekerasan Permukaan SUS 304 Pada Proses Laser Cutting Menggunakan Gas N2. Thesis. Malang: Universitas Brawijaya. 2018

[8] Pangerapan, L,S. Pengolahan Material Akrilik untuk Diaplikasikan sebagai Produk Aksesoris Perhiasan Wanita. Thesis. Bandung: Universitas Telkom. 2017

[9] Prihandianto, B,D. Optimasi Parameter Pemotongan Polymethyl Methacrylate pada Mesin Laser Cutting CO2. Thesis. Yogyakarta: Universitas Gadjah Mada. 2015. 